Images in...

\title{
Reversible cerebral vasoconstriction syndrome in a postpartum female complicated by subarachnoid haemorrhage
}

Rasheed Zakaria, ${ }^{1}$ lan Coulter, ${ }^{1}$ Peter Enevoldson, ${ }^{2}$ Paul May ${ }^{1}$

${ }^{1}$ Neurosurgery, The Walton Centre NHS Foundation Trust, Merseyside, Liverpool, UK:

${ }^{2}$ Neurology, The Walton Centre NHS Foundation Trust, Merseyside, Liverpool, UK

Correspondence to Mr Rasheed Zakaria rzakaria@nhs.net

\section{DESCRIPTION}

A 31-year-old woman experienced sudden onset parietooccipital headache 2 days postpartum. This resolved spontaneously but recurred at 6 days postpartum, when she reported the worst occipital headache she had ever experienced. Neurological examination was unremarkable. A non-contrast CT scan of the brain revealed subarachnoid haemorrhage (SAH) predominantly distributed

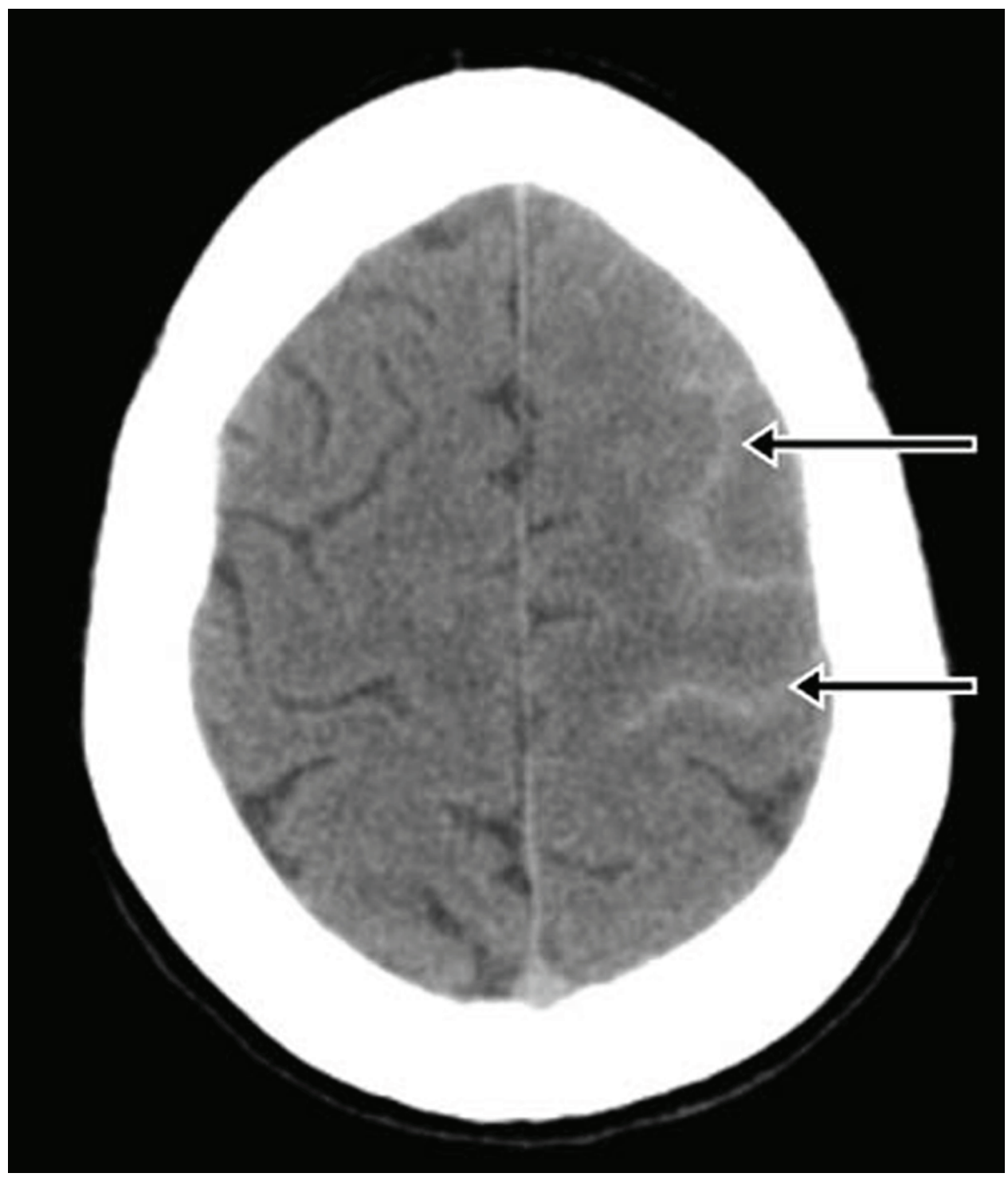

Figure 1 Non-contrast CT scan of the brain taken at initial presentation demonstrating convexity subarachnoid haemorrhage over the cortical surface as opposed to the more common patterns of blood seen after aneurysmal bleeds. 


\section{BMJ Case Reports}

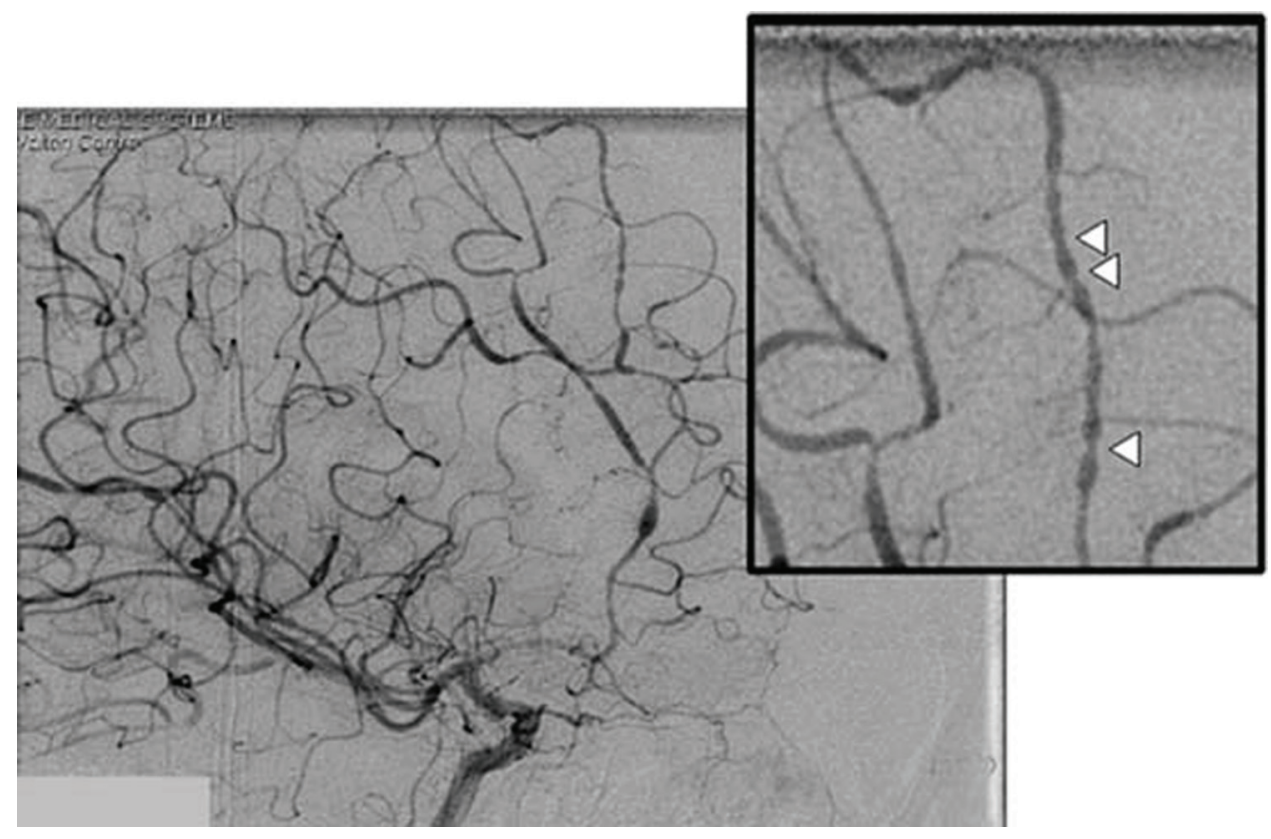

Figure 2 Digital subtraction angiography - left internal carotid injection showing the characteristic findings of dilated and constricted arteries due to vasospasm, grossly and inset in more detail.

in a superficial cortical pattern (figure 1). The patient was urgently transferred to a neurosurgical unit and underwent cerebral digital subtraction angiogram which demonstrated multiple areas of arterial stenosis and dilatation, suggestive of diffuse vasospasm (figure 2). Blood tests for vasculitis and autoimmune disease, urine toxicology screen and cerebrospinal fluid analysis were normal.

Reversible cerebral vasoconstriction syndrome is chracterised by sudden severe headache with cerebral arterial vasoconstriction which spontaneously resolves. It is more prevalent in females and around two thirds of cases are secondary to pregnancy or vasoactive substances including cannabis, cocaine, esctasy, amphetamines and binge drinking. Patients are said to complain of an intense sudden onset headache which may relapse and remit as here. Neurological deficits and seizures may occur at presentation. A quarter to a third will have raised blood pressure during the episode.
Investigations are often directed to excluding aneurysmal subarachnoid bleed and non-contrast CT may show SAH in $20 \%$, usually cortical. Infarction and intracerebral haemorrhage are less common at around 5\%. ${ }^{1}$ Angiogram is definitive with the so-called 'string of beads' finding of segmenetal narrowing and dilatation as illustrated here. Nimodipine (60 mg six times daily), which was given here, is said to speed resolution, though more recently aggressive endovascular interventional techniques such as intra-arterial vasodilators and angioplasty have been employed. ${ }^{2}$

Competing interests None.

Patient consent Obtained.

\section{REFERENCES}

. Ducros A, Bousser MG. Reversible cerebral vasoconstriction syndrome. Pract Neurol 2009;9:256-67.

2. Farid $\mathbf{H}$, Tatum JK, Wong $\mathrm{C}$, et al. Reversible cerebral vasoconstriction syndrome: treatment with combined intra-arterial verapamil infusion and intracranial angioplasty. Am J Neuroradiol 2011 (In Press).

This pdf has been created automatically from the final edited text and images.

Copyright 2011 BMJ Publishing Group. All rights reserved. For permission to reuse any of this content visit http://group.bmj.com/group/rights-licensing/permissions.

BMJ Case Report Fellows may re-use this article for personal use and teaching without any further permission.

Please cite this article as follows (you will need to access the article online to obtain the date of publication).

Zakaria R, Coulter I, Enevoldson P, May P. Reversible cerebral vasoconstriction syndrome in a postpartum female complicated by subarachnoid haemorrhage. BMJ Case Reports 2011;10.1136/bcr.06.2011.4342, date of publication

Become a Fellow of BMJ Case Reports today and you can:

- Submit as many cases as you like

- Enjoy fast sympathetic peer review and rapid publication of accepted articles

- Access all the published articles

- Re-use any of the published material for personal use and teaching without further permission

For information on Institutional Fellowships contact consortiasales@bmjgroup.com

Visit casereports.bmj.com for more articles like this and to become a Fellow 